\title{
Integrated Site Suitability Analysis for Urban Development Using Remote Sensing and GIS Based Multicriteria Evaluation Technique in Wolaita Sodo Town and Surrounding Area, SNNPR, Ethiopia
}

\author{
Mesfin Girma Mamo \\ Lecturer, Department of Civil Engineering, Wolaita Sodo University, SNNPR, Ethiopia
}

\begin{abstract}
Urban Land suitability assessment is an important fundamental work in urban land development. Land suitability assessment, in the context of land use planning, is a bridging phase linking land resources assessment to any land use decision-making process. This study demonstrates the use of Geographic Information System (GIS) tools and numerical Multi-Criteria Evaluation (MCE) techniques for selection of suitable sites for urban development of a Sodo Town and surrounding area. Six factors (land use, road proximity, soil type, river proximity, geomorphology and slope) were identified for criteria evaluation. Weights for each criterion are generated by comparing with each other according to their importance. Criteria weights was develop by employing GIS based Multi-Criteria Decision Analysis (MCDA) such as Analytical Hierarchy Process (AHP) for evaluating the suitability of the urban land site selection. Pair wise comparison matrix indicates weights for land use $(=0.3729)$, road proximity $(=0.1440)$, soil type $(=0.1826)$, river proximity $(=0.0714)$, geomorphology $(=0.1777)$ and slope $(=0.0514)$. Consistency Ratio, $(\mathrm{CR}=0.01)<0.10$ indicated a reasonable level of consistency in the pair wise comparisons. After the final suitability analysis map was obtained from weighted overlay in Arc GIS Spatial Analyst Tools; it was found that from the available area $19.234 \mathrm{sq} \mathrm{km}$ falls under low suitable, $4.579 \mathrm{sq}$. km under moderately suitable and $5.048 \mathrm{sq}$. km under high suitable. The result shows that highly suitable areas for urban development is agricultural land and open forest.

Keywords: Urban Land suitability, Geographic Information System (GIS); Remote Sensing (RS); Multi-criteria Evaluation (MCE); Analytic Hierarchy Process (AHP); Spatial Analysis tool.
\end{abstract}

DOI: $10.7176 / \mathrm{JEES} / 9-5-01$

Publication date:May $31^{\text {st }} 2019$

\section{Introduction}

Urban land as a part of the earth's surface has reasonably stable or predictable repeated activity and its suitability for agriculture, settlement and industry depends on its elements [2]. Due to the increasing population and economic growth, human activities have continuous impacts on land use. Those impacts might lead to a series complexities toward environment and land resources development [1].

Urban land suitability analysis is fundamental to land management decisions, planning and utilization, providing a link between resources assessment and the decision-making process. Land suitability for specific purposes is assessed by land-use suitability analysis [10]. This decision-making process considers not only the natural attributes of the land but also its socioeconomic and environmental features. In other words, land use decisions are based on complex, interrelated factors such as: the characteristics of the land itself; economic conditions; social, environmental and political constraints; and the objectives and needs of the land users [9].

Several articles have been published in addressing urban land suitability using Multi Criteria Evaluation (MCE) integrated in Geographical information System environment. In recent years, extensive interest has grown around the use of GIS technology for planning and management of environmental resources. One major and useful application of GIS to planning and management is the evaluation of land for its suitability for a particular utility [7]. Many of GIS-based land suitability analysis approaches such as Boolean overlay and modelling for land suitability analysis lack a well-defined mechanism for incorporating the decision-maker's preferences into the Geographic Information System (GIS) procedures. This may be solved by integrating GIS and Multi Criteria Evaluation (MCE) methods [3]. Among the various MCE methods, the Analytical Hierarchy Process (AHP) is a well-known multi-criteria technique that has been incorporated into GIS-based suitability procedures to obtain the required weightings for different criteria.

\subsection{Objective}

The main objective was to identify land that is suitable for urban development based on remote sensing and GIS based multicriteria evaluation technique in Wolaita Sodo Town and surrounding area.

\subsubsection{Specific objectives of the study:}

\# To develop physical land suitability map.

* To suggest the best site suitable for urban development and growth. 


\section{Description of The Study Area}

Wolaita Sodo Town, one of the oldest Town in the SNNPR is formed as Town 113 years ago as military center to the south, to make a united one Ethiopia by the Emperor Minlik the secondary of Ethiopia. One of the 22 reform cities in SNNPR \& has got a secondary level next to Hawassa. It is the administrative capital of the Wolaita zone. In addition the Town functions as a center for the surrounding agricultural land. It is also a major transportation node, being the center of six national and regional transport router. Trade is the most important lively hood of the resident of the Town. Sodo Town is located $390 \mathrm{~km}$ of south $167 \mathrm{~km}$ of south west of Addis Ababa and Hawassa respectively. Astronomically the Town is located $6^{0} 49^{\prime} \mathrm{N}$ latitude and $37^{0} 45^{\prime}$ E longitude. The Town is divided in to three sub town, 11 kebeles and 99 villages (mender). The Town is established at the foot of mount Damot \& from these mountains; its altitude descends to south directions. The highest \& lowest altitude of the town range from 2,222-1,600 meters above sea level. The mean annual temperature of the town is $20^{\circ} \mathrm{c} \&$ the mean annual rainfall is $1,200 \mathrm{~mm}$.

Population size of the Town, according to the data from city finance Economic Development office recently the total number of the Town's residents exceed 120,000. However the office says that the number of population is increasing in high level due to continues rural-urban migration. To this end, the annual growth rate of the Town's population is 5.4\%. The Town is located in the strategic place for the southern Ethiopia at the center and it has 6 outlets which are connect the north, south, east and west areas.

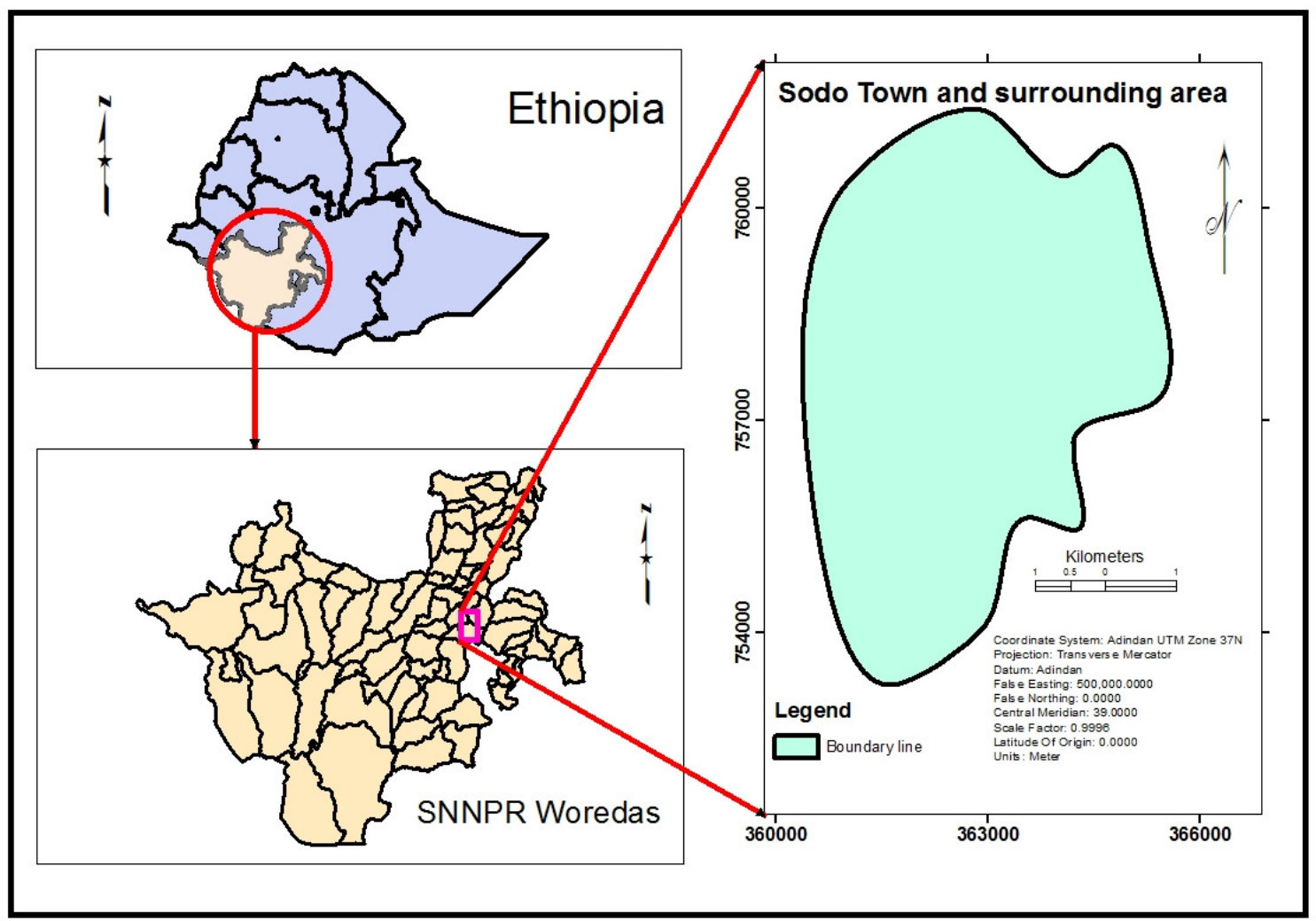

Figure 1. Location map of the study area

\section{Materials and Methods}

The key principle behind urban land suitability analysis is the cartographic modeling approach in which a set of map operations is performed on input maps of a study area to create a spatial model $[4,5]$. Suitability analysis can be conducted in GIS by using either a vector data or a raster data model. GIS based urban site suitability is the process of understanding existing site qualities and factors, which will determine the location of a particular activity. The purpose of selecting potential areas for residential development depends upon the relationship of different factors, like location of available sites, extent of the area, accessibility, etc. and site association factors like slope, soil etc. The analysis may also determine how those factors will fit into the design process to evaluate site suitability [13].

The purpose of this chapter is to present fundamental materials and methods applied to obtain the required data from respective sources and a research design describes a procedural adopted to answer the research objectively, accurately. Method includes the following concepts as they relate to a particular discipline or field of inquiry like collection of theories, concepts or ideas, comparative study of different approaches; and critique of 
the individual. Therefore a research method provide answer for such questions as what techniques will be used to gather the data, what kind of model used to make analysis and presentation of the results.

\subsection{Materials}

\subsubsection{Data Sources}

Different data source were refereed to analyses the land suitability of the study area because the most important thing in making research is source of data. Data help to reach the final result, which was designed earlier in the objectives. Different types of data were utilized to attain the objectives in this paper.

Table 1. Key factors and parameters for urban development suitability evaluation.

\begin{tabular}{|l|l|l|}
\hline Factors & Parameters & Data Sources \\
\hline \multirow{2}{*}{$\begin{array}{l}\text { Environmental } \\
\text { Background }\end{array}$} & Soil Map & EMWRO \\
\cline { 2 - 3 } & Elevation (DEM) & Downloaded from earth explorer \\
\cline { 2 - 3 } & Geomorphological type & EMWRO \\
\hline \multirow{2}{*}{ Water/Land resource } & Land use & Landsat ETM+ 2018 downloaded from Earth explorer \\
\cline { 2 - 3 } & River proximity & Developed by digitizing Google earth map. \\
\hline $\begin{array}{l}\text { Socio-economic } \\
\text { development }\end{array}$ & Road proximity & Developed by digitizing Google earth map. \\
\hline
\end{tabular}

\subsubsection{Softwares for image and data processing}

Software used in this study was selected based on the capability to work in achieving the predetermined objectives. ERDAS 2014 was used for image processing activities on satellite images. The factor map development was carried out using ArcGIS10.4.1 Software package. The factors that are input for multi-criteria analysis should be preprocessed in accordance to the criteria set to urban land suitability analysis. So, using spatial Analyst and 3D Analyst extension, some relevant GIS analyses were undertaken to convert the collected shape files. IDRISI 32 was also used for weight module determination.

\subsection{Methods}

In order to conduct the study, a step by step method was followed in this research. The workflow of the research can be shown by figure 2. During the preliminary studies a number of literatures were reviewed and the study area was selected. Based on preliminary studies the requirement analysis was done for setting data requirements and for getting criteria affecting the urban land use suitability analysis. Then, geodatabase was created. The data was collected and was exported into geodatabase. Further literature reviews were done for calculating Eigen Values using AHP methodological operations. The Eigen Values show the degree of priority of the criteria. Using Eigen Values raster criterion maps were prepared from data available in geodatabase. These criterion maps were overlaid to develop a composite map which later was classified to prepare suitability map. Finally, using the suitability map urban land suitability was suggested. 


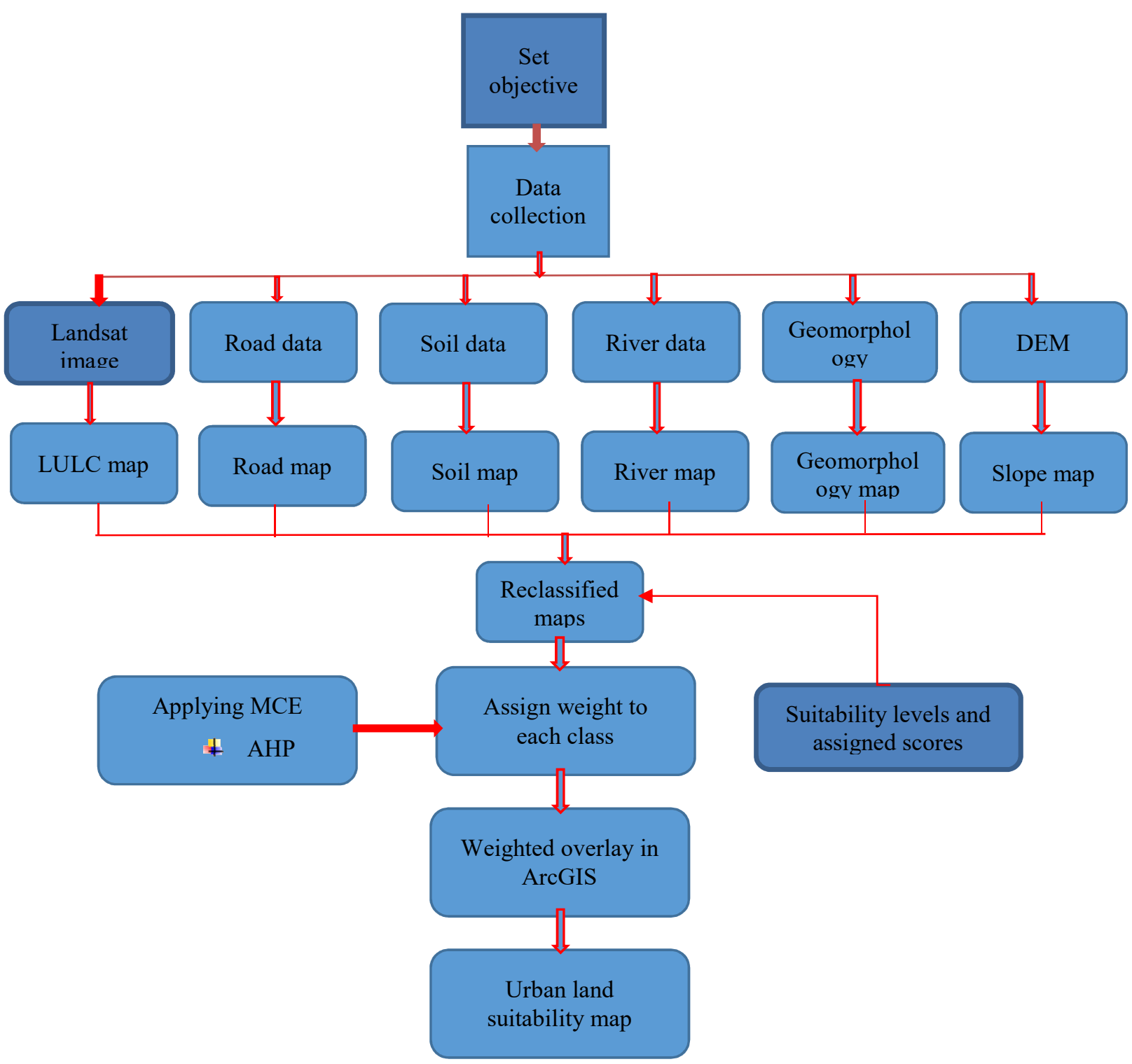

\subsubsection{Factors Development}

Figure 2. Work flow of the research method

\subsubsection{Land use \& Land Cover map}

Land use is the main basis for urban land suitability analysis; the distribution of various land-use types gives considerable constraints to urban land development. Land-use map of the study area was prepared from LANDSAT satellite image acquired on 2018 and supervised digital image classification technique was employed using ERDAS IMAGINE 2014 software. Five different classes of land use have been categorized i.e. closed forest, agricultural land, open forest, built-up area, and bare land. The closed forest covers the total area of $3.773 \mathrm{~km}^{2}$, agricultural land covers an area of about $7.440 \mathrm{~km}^{2}$, open forest covers an area of about $7.584 \mathrm{~km}^{2}$, built-up area covers an area of about $7.198 \mathrm{~km}^{2}$ and the bare land covers an area of about $2.866 \mathrm{~km}^{2}$. 


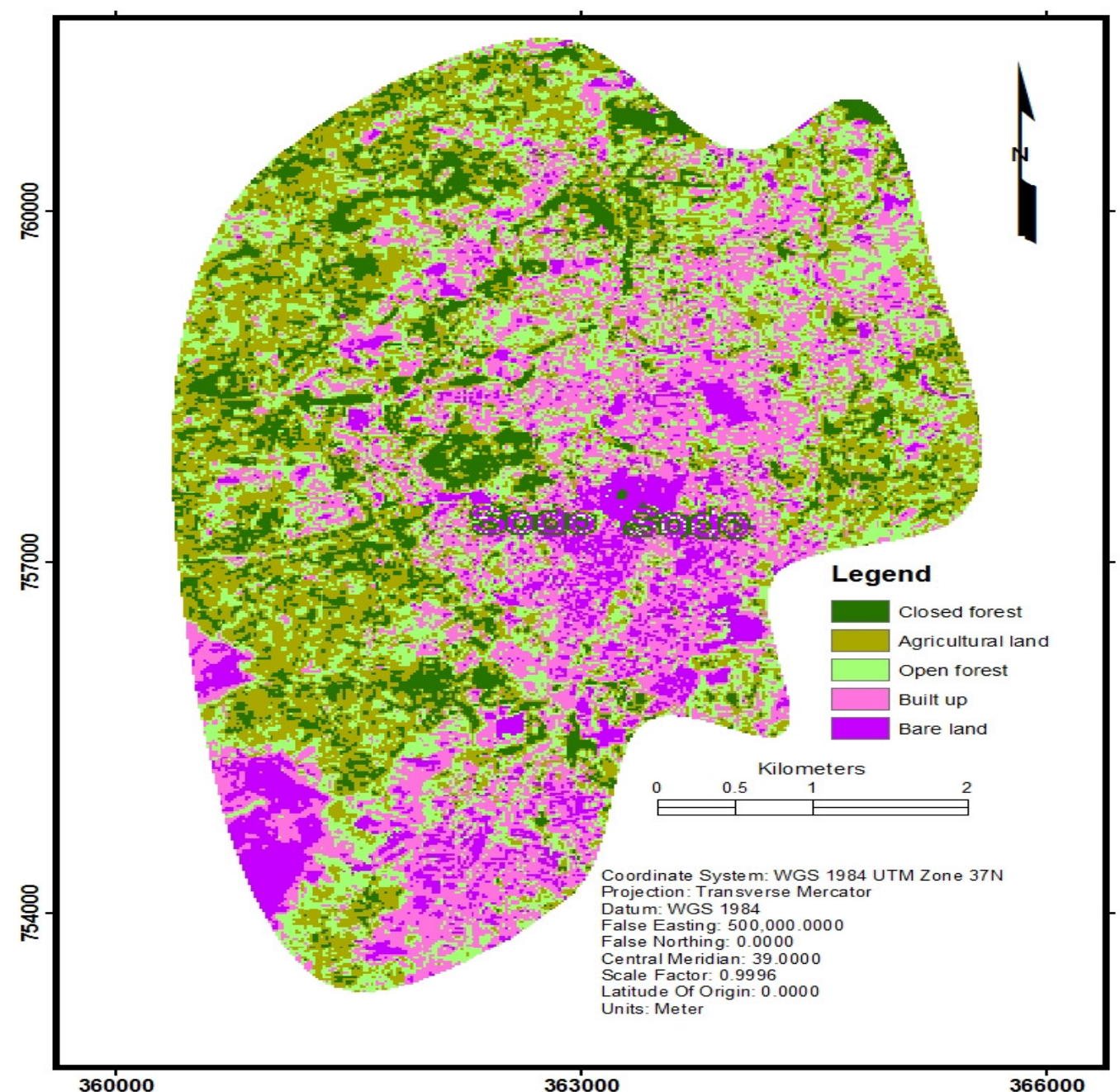

Figure 3. Land use /cover classes

\subsubsection{Road Proximity map}

The road network plays a very important role in the urban development. The road networks were digitized from the Google earth map. As more settlement develops near the road networks because of the transportation facilities and very easy access to the nearby places and city centers. The five different classes' of proximity regions for road networks were generated, $100 \mathrm{~m}, 200 \mathrm{~m}, 300 \mathrm{~m}, 400 \mathrm{~m}$, and $500 \mathrm{~m}$ proximity respectively. High weightage has been given for $100 \mathrm{~m}$ class as the development of settlements and multi-story buildings are highly possible near the road networks. Low weightage has been given for 500m proximity class as there are fewer chances for the development of settlements away from road networks. 


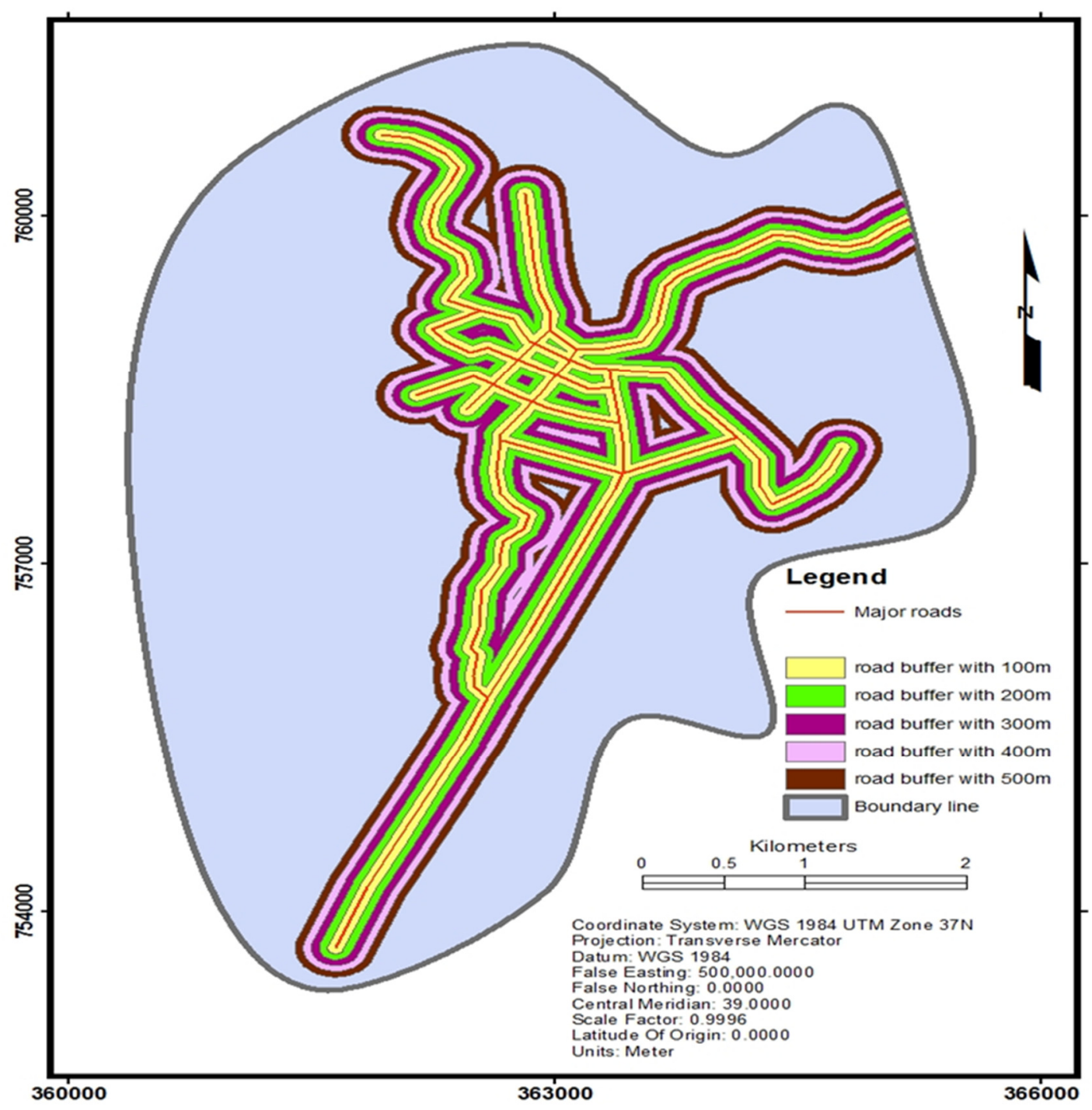

\subsubsection{Soil factor map}

Figure 4. Road proximity buffer zones

Soil is the most important criterion for determining an area's suitability for urban construction. Joshua et al. (2013) as cited [12] identified which soil types have high fertility, nutrient deficiency and high water holding capacity and can be used for urban areas. The soil types in the study area are dystric Nitisols, chromic Luvisols and chromic Vertisols.

Nitisols are marked by deep, porous solum, well drained and easy to plough. Moreover, good texture, high organic matter, BS and CEC characterize the Nitisols. Thus they are generally considered as fertile and productive soils. , However, the level of Nitrogen and the imbalances of nutrients need to be corrected to enhance the productivity of the soils. Luvisols are fertile for its high organic matter, available bases and CEC and also intensively cultivated soils. The most constraint of soils, however, is soil acidity [14].

Vertisols soil has good workability, good drainage, and adequate soil depth. The vertisols on the other hand, pose different problems. They are inherently fairly fertile with good moisture holding characteristics, and a welldeveloped structure when dry. However, they have a narrow range of moisture outside of which they are hard when too dry and very sticky when too wet. 


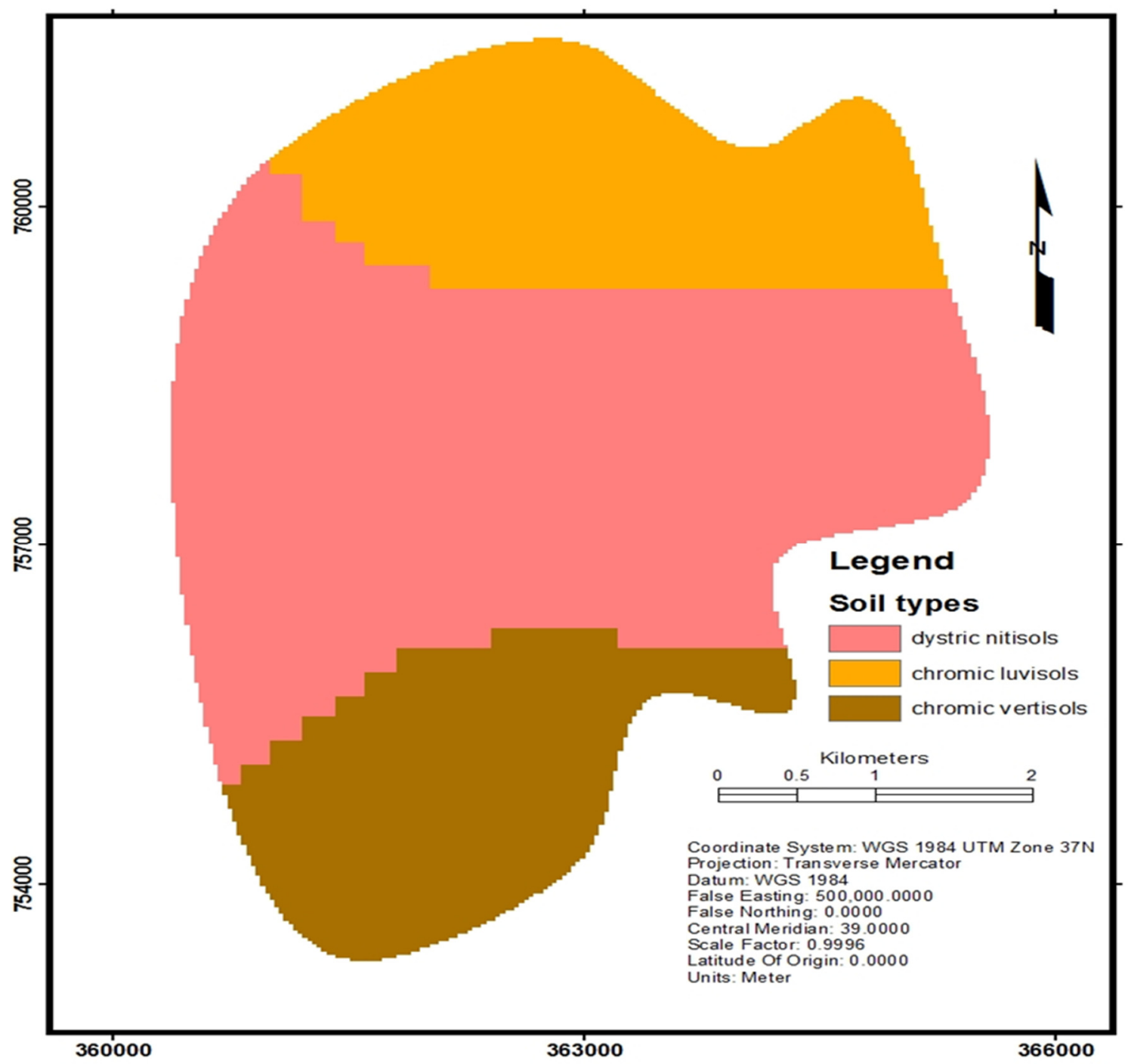

\subsubsection{Rivers Proximity map}

Figure 5. Soil map of the study area.

In this study, the rivers have been mapped by digitizing from the Google earth image. The area near the water bodies develops more rapidly than the area which is away from the surface water bodies. Accordingly, analysis tools were used to prepare multiple polygons around each river within the following distances: $100 \mathrm{~m}, 200 \mathrm{~m}$, $300 \mathrm{~m}, 400 \mathrm{~m}$, and $500 \mathrm{~m}$ proximity respectively. The proximity map was reclassified into five classes and weights were calculated using data analysis. Accordingly, more weightage was assigned for more suitable areas $100 \mathrm{~m}$. Low weightage was given for $500 \mathrm{~m}$ proximity class. 


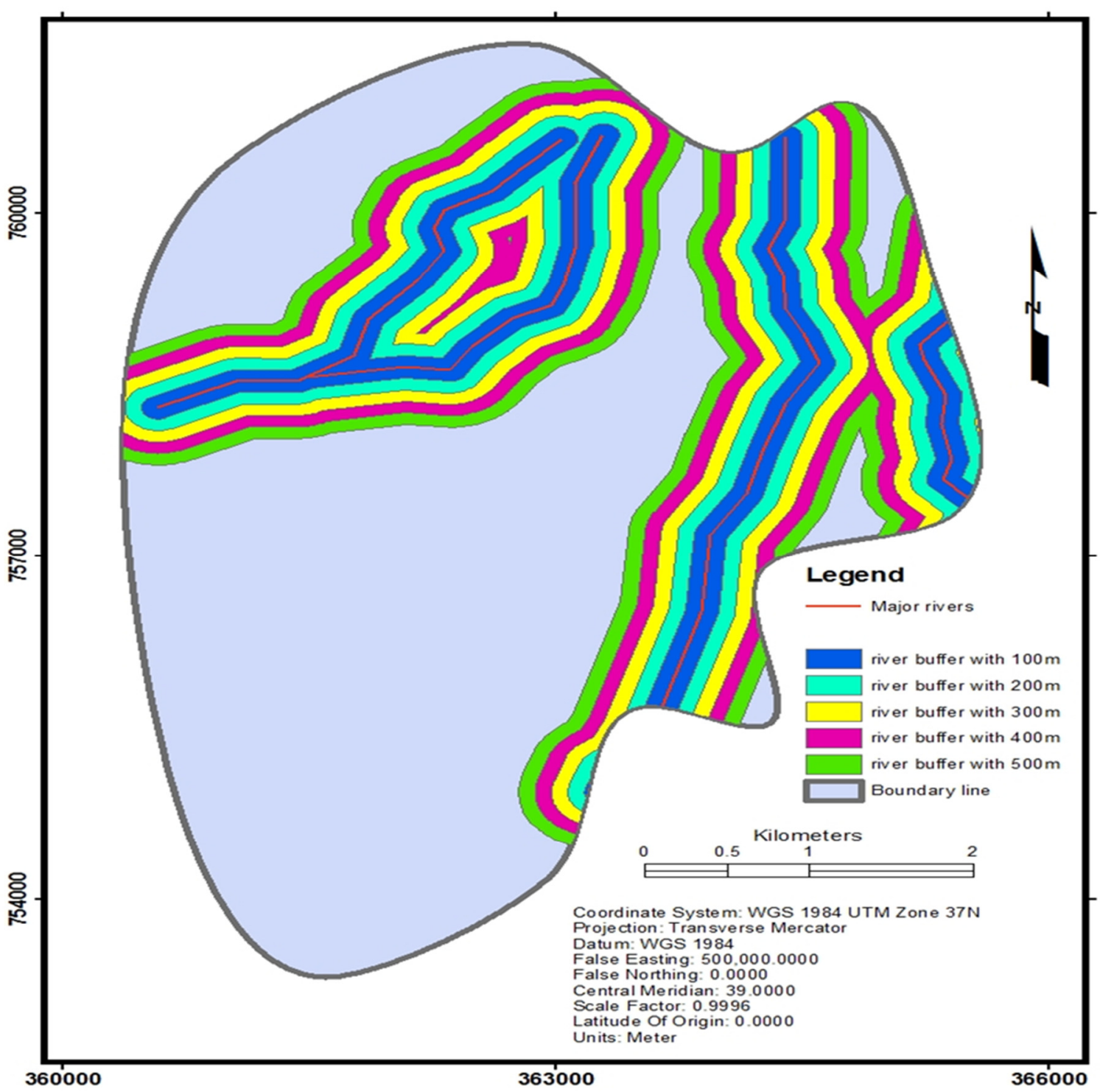

\subsubsection{Geomorphology map}

Figure 6. River proximity buffer zones

Geomorphology can be defined as a science which studies the genesis and the causes of evolution of land surfaces and their rate of change in relation to nature and human. Geomorphologic studies aim at describing the present nature of the topography and interpreting the causes of its formation. The study area contains high Plateaux; high to mountationous relief hills; plains and low plateaux with hills moderately dissected side slopes and dissescted plains. Fig 7 shows the area distribution of the various geomorphology map of the study area. 


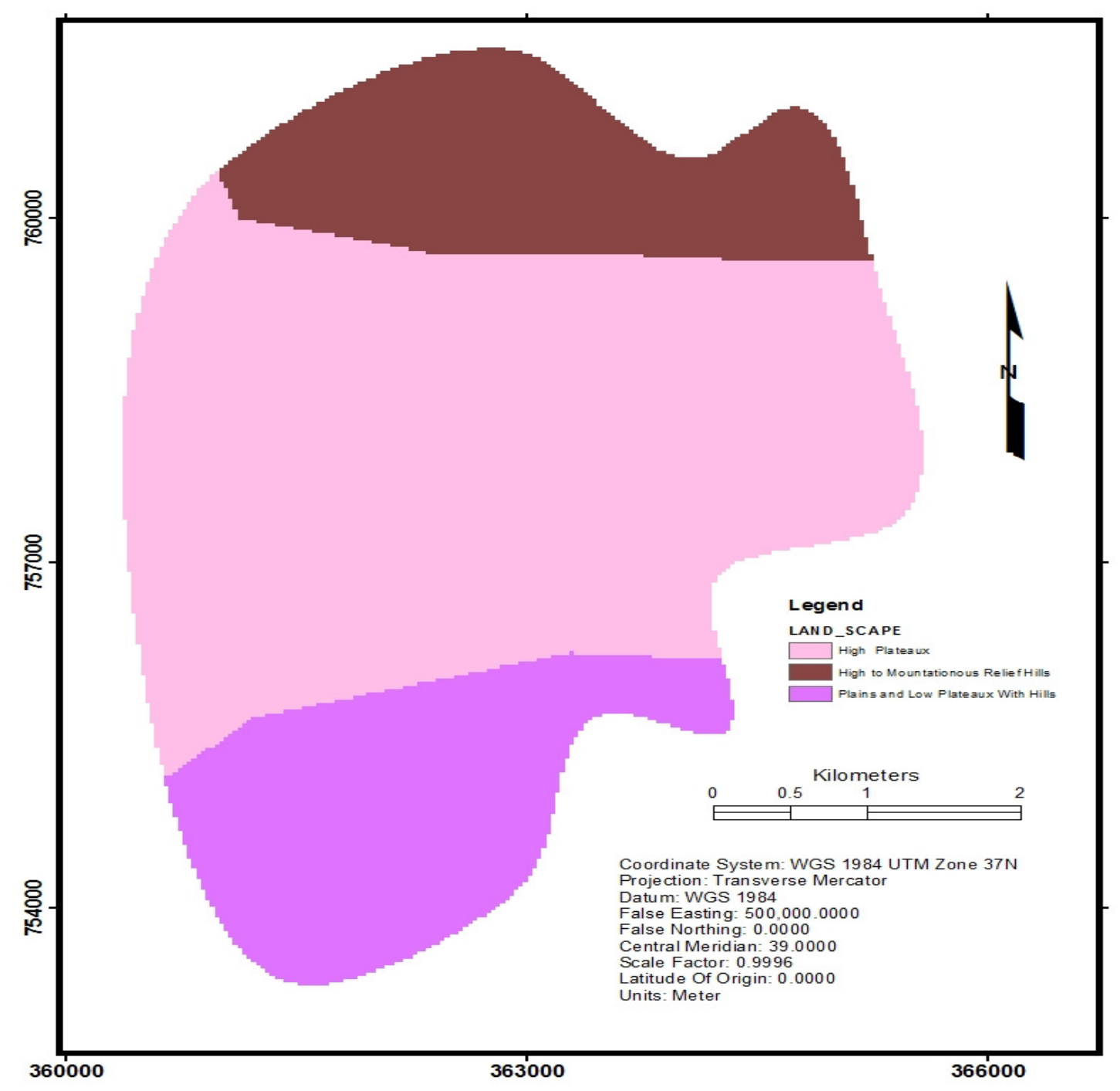

\subsubsection{Slope factor map}

Figure 7. Geomorphology maps of study area

Slope is one of the basic criteria to be considered in economic terms. It is suggested to select flat areas for development and continuity of the urban growth. The DEM presents in the study area ranging from $1600-$ $2,222 \mathrm{~m}$ above sea level. The DEM was used for the generation of the slope map of the area with the help of ArcGIS tool called Slope, the extension tool of the 3D Analysis tools. Slope has categorized in to 5 classes in degree. Fig 8 below shows the area distribution of the various slope map of the study area. 


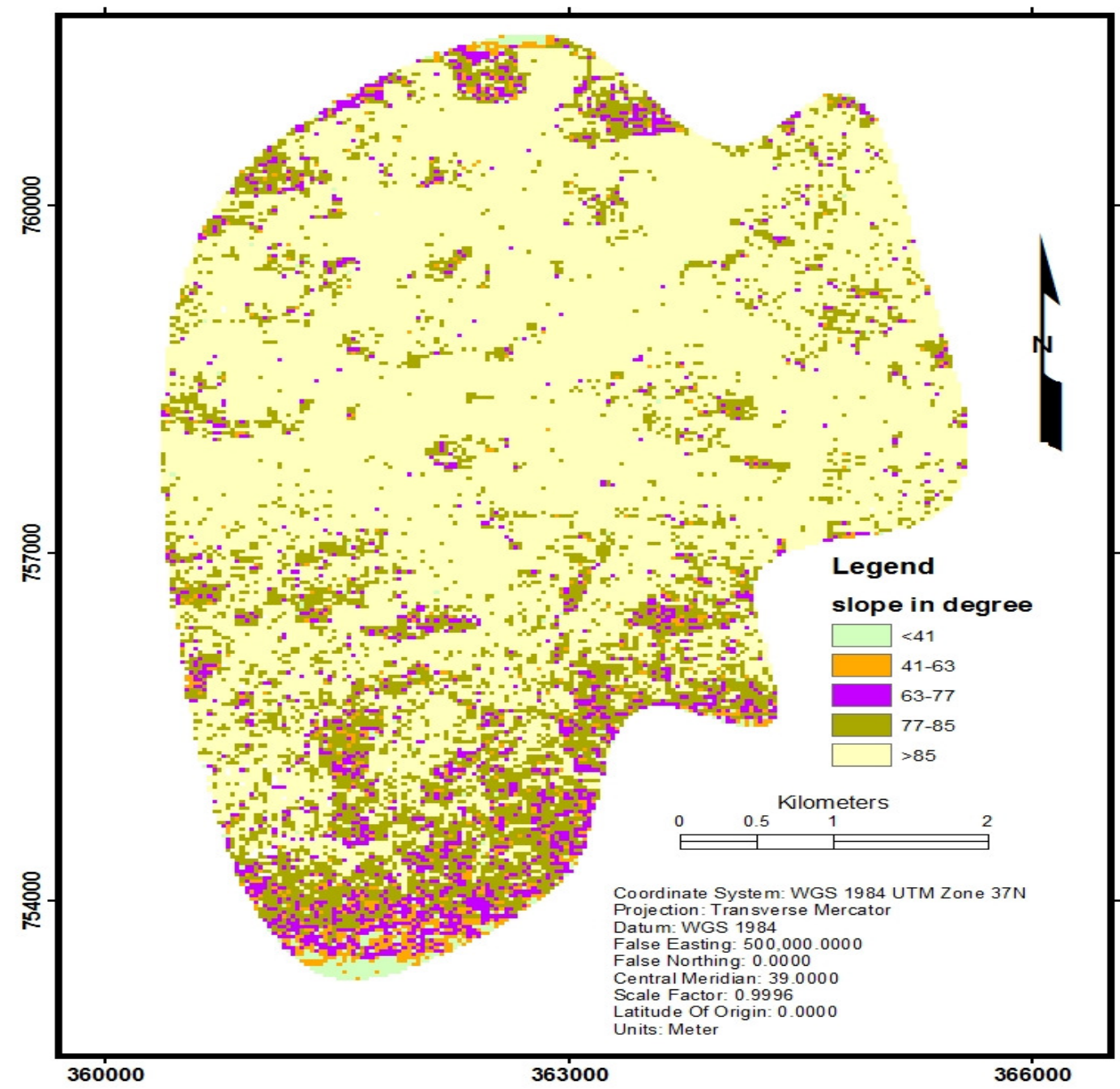

Figure 8. Slope map of the study area.

\section{Analysis and Result}

\subsection{Analytic Hierarchy Process (AHP)}

AHP is one of the most popular Multi-Criteria Decision Making Model (MCDM) techniques developed by Saaty (1980). It is used to identify the best one from a set of alternatives with respect to several criteria. The basic principle of AHP is to solve a problem by forming hierarchies. To ensure the credibility of the relative significance used, AHP also provides measures to determine inconsistency of judgments mathematically.

Based on the properties of reciprocal matrices, the consistency ratio (CR) can be calculated. $\mathrm{CR}<0.10$ indicates that level of consistency in the pair wise comparison is acceptable. Saaty (1980) suggests that if CR is smaller than 0.10 , then the degree of consistency is fairly acceptable. But if it is larger than 0.10 , then there are inconsistencies in the evaluation process, and AHP method may not yield meaningful results.

The standardized raster layers were weighted using Eigen vector that is important to show the importance of each factor as compared to other in the contribution of urban land suitability analysis. Accordingly, the Eigen vector of the weight of the factors was computed in IDRISI 32 software in analysis menu decision support/ weight module. In this study, a pair of criteria were valued at the same time using the scale of nine points (degrees) ranging from1/9 to 9 as shown in Table 2.

Table 2. Continuous rating scale used for the pair wise comparison of factors in the multi-criteria evaluation, Saaty (1977)

\begin{tabular}{|l|l|l|l|l|l|l|l|l|}
\hline $1 / 9$ & $1 / 7$ & $1 / 5$ & $1 / 3$ & 1 & 3 & 5 & 7 & 9 \\
\hline extremely & Very & Strongly & Moderately & $\begin{array}{l}\text { Equally } \\
\text { important }\end{array}$ & Moderately & Strongly & Very & extremely \\
\hline \multicolumn{3}{|c|}{ Less important } & \multicolumn{7}{c|}{ More important } \\
\hline
\end{tabular}


The computed Eigen vector, which is an output of the pairwise comparison matrix to produce a best fit set of weight, of Weight Module was:

Land use/Land cover

Road proximity

Soil type

0.3729

Rivers Proximity

Geomorphology

Slope

\begin{tabular}{|c|}
\hline 0.1440 \\
\hline 0.1826 \\
\hline 0.0714 \\
\hline 0.1777 \\
\hline
\end{tabular}

The critical ratio of the calculated Eigen vector is 0.01 which is acceptable. The computed Eigen vector is used as a coefficient for the respective factor maps to be combined in Weighted Overlay in Arc GIS environment.

\subsection{Overlaying map layers}

Afterward preparation of maps of all features like road buffer, soil type, river buffer and geomorphology were converted to raster files and separate datasets were created using weightage and rank. For different layers having different scores were laid and the scores of each composite class were added. Finally, the suitability map was prepared.

Table 3. Factors weightage

\begin{tabular}{|c|c|c|c|}
\hline Factor & Class & Ranking & Weight \\
\hline \multirow[t]{5}{*}{ Land use/Land cover } & Bare land & 9 & \multirow[t]{5}{*}{0.3729} \\
\hline & Agricultural land & 8 & \\
\hline & Closed forest & 6 & \\
\hline & Open forest & 4 & \\
\hline & Built-up land & 2 & \\
\hline \multirow[t]{5}{*}{ Road proximity } & 100 & 9 & \multirow[t]{5}{*}{0.1440} \\
\hline & 200 & 8 & \\
\hline & 300 & 6 & \\
\hline & 400 & 4 & \\
\hline & 500 & 2 & \\
\hline \multirow[t]{3}{*}{ Soil type } & dystric Nitisols & 6 & \multirow[t]{3}{*}{0.1826} \\
\hline & chromic Luvisols & 4 & \\
\hline & chromic Vertisols & 2 & \\
\hline \multirow[t]{5}{*}{ Rivers Proximity } & 100 & 9 & \multirow[t]{5}{*}{0.0714} \\
\hline & 200 & 8 & \\
\hline & 300 & 6 & \\
\hline & 400 & 4 & \\
\hline & 500 & 2 & \\
\hline \multirow[t]{3}{*}{ Geomorphology } & Plains and low plateaux with hills, moderately dissected & 6 & \multirow[t]{3}{*}{0.1777} \\
\hline & High plateaux & 4 & \\
\hline & High to mountationous relief hills & 2 & \\
\hline \multirow[t]{5}{*}{ Slope } & $<41$ & 9 & \multirow[t]{5}{*}{0.0514} \\
\hline & $41-63$ & 8 & \\
\hline & $63-77$ & 6 & \\
\hline & $77-85$ & 4 & \\
\hline & $\exists 85$ & 2 & \\
\hline
\end{tabular}

According to FAO (1993) the suitability classification standard is famous for land suitability analysis. The standard establishes whether a land is highly suitable or not suitable. It is split into five suitability ratings. This case study used three of the important ratings of land suitability ratings to generate the results. The three ratings are high suitability, moderate suitability, and low suitability, as shown in table 4 below.

Table 4. Explanation of the land suitability ratings used in the study (Source: FAO, 1993).

\begin{tabular}{|l|l|l|}
\hline Low suitability & Moderate suitability & High suitability \\
\hline 1 & 2 & 3 \\
\hline $\begin{array}{l}\text { Land with limitations so severe that } \\
\text { benefits are reduced and/or the } \\
\text { inputs needed to sustain production } \\
\begin{array}{l}\text { are increased so that this cost is only } \\
\text { marginally justified. }\end{array}\end{array}$ & $\begin{array}{l}\text { Land that is clearly suitable but which has } \\
\text { limitations that either reduce productivity } \\
\text { or increase the inputs needed to sustain } \\
\text { productivity compared with those needed } \\
\text { on highly suitable land. }\end{array}$ & $\begin{array}{l}\text { The land can support } \\
\text { the } \\
\text { indefinitely } \\
\text { benefits justify inputs. }\end{array}$ \\
\hline
\end{tabular}

In order to have final suitability analysis, six different criteria maps are converted into raster format. A GIS 
Spatial analysis in which models are represented as a set of spatial processes, such as buffer, classification, and reclassification and overlay techniques. Each of the input themes is assigned a weight influence based on its importance.

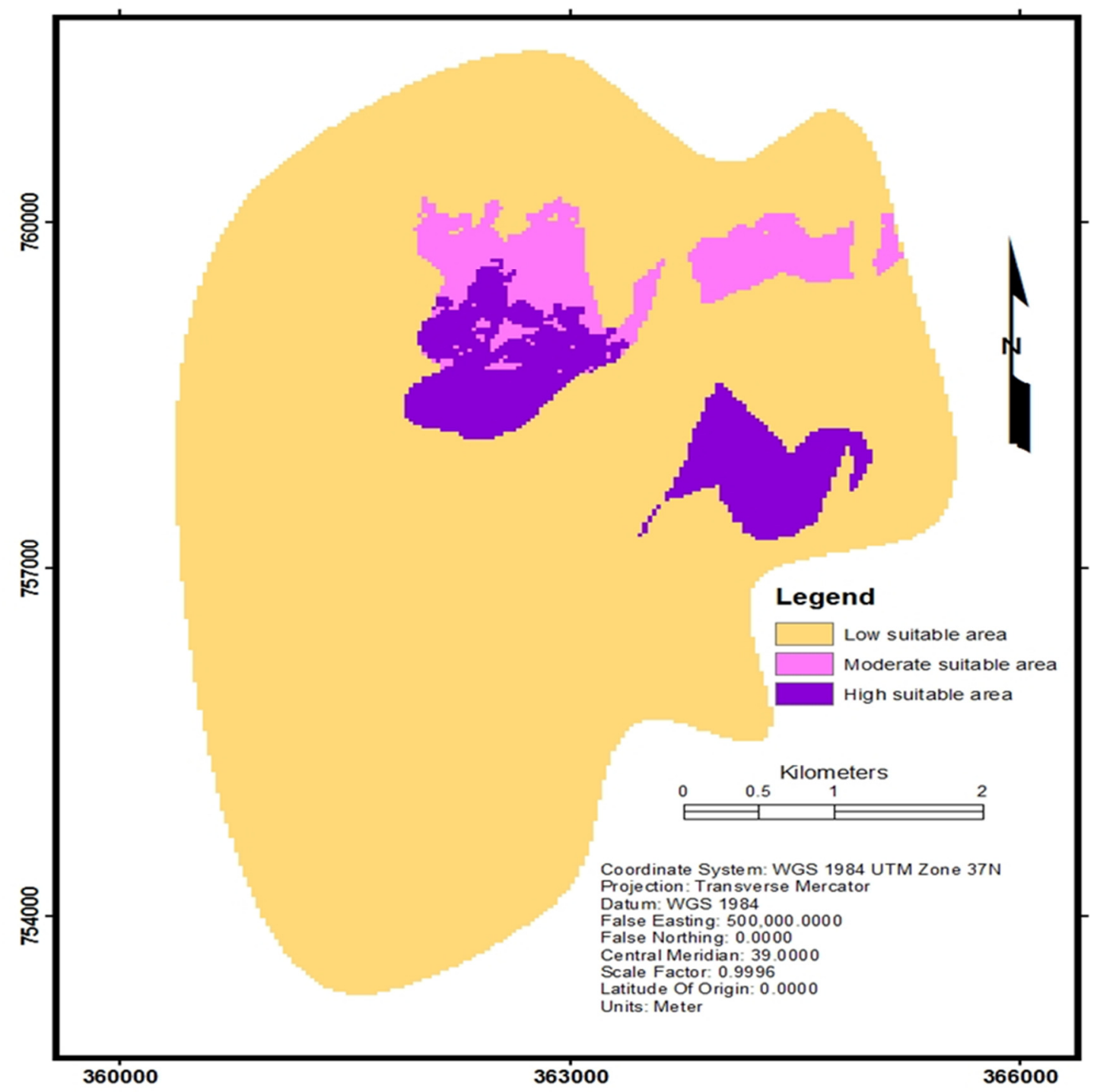

Figure 9. Final urban land suitability map

The procedure for land suitability analysis for the urban development relied on GIS based weighted overlay of the factor maps on this paper. The result indicates that 66.644 percent land is low suitable, 15.866 percent is moderate suitable and 17.490 percent is high suitable for urban development.

Table 5. Land area at different levels of suitability

\begin{tabular}{|l|l|l|}
\hline Level of suitability & Area $\left.\mathbf{( k m}^{\mathbf{2}}\right)$ & percentage \\
\hline Low suitability & 19.234 & 66.644 \\
\hline Moderate suitability & 4.579 & 15.866 \\
\hline High suitability & 5.048 & 17.490 \\
\hline Total & 28.861 & 100 \\
\hline
\end{tabular}

\section{Conclusion and Recommendation}

This chapter provides the concluding part of this paper. It states the main contribution of this study by relating the findings with the objectives of this study. Finally this chapter suggests further study recommendation.

\subsection{Conclusion}

A suitability map was created based on the approach that was adopted. The study was focused on use of integrated Remote sensing and multi-criteria AHP with GIS to determine the suitability of the urban land deployment of Sodo Town and surrounding area. The result of this study indicated that out of the total area of 
$28.861 \mathrm{~km}^{2}, 17.49 \%\left(5.048 \mathrm{~km}^{2}\right)$ are most suitable for urban development, $15.866 \%\left(4.579 \mathrm{~km}^{2}\right)$ are moderately suitable for urban development and $66.644 \%\left(19.234 \mathrm{~km}^{2}\right)$ of the area is least suitable for urban development. Therefore, this study presented the advantages of integrated GIS-based land suitability analysis and a solution for such complicated decisions.

\subsection{Recommendation}

After analysis of the study, certain recommendations can be made. The following can be recommended for suitable urban land development:

$\checkmark$ The combination of GIS with AHP is powerful tool for land suitability analysis for urban development. The method requires only little computer skills within a GIS environment. Therefore, GIS-based AHP for land suitability has proven to facilitate efficiency from the economic point of view as compared to the traditional methods.

$\checkmark$ Land-use strategy must take account of land suitability in relation to the expected future needs and the possibility of meeting demands. The critical importance of land for specified uses should be known either physical or economic suitability. This means not only whether it is important that this specific area of land should be used in particular way but also whether a particular area is physically suitable.

$\checkmark$ An urban development land-use suitability mapping approach has been constructed, based on opportunity and constraint criteria.

$\checkmark \quad$ In the future study this method can be applied for mapping land suitability of other urban development in the county and across the country with additional and more refined parameters.

\section{List of Reference}

[1] Huang, G., Xia, J. (2001) Barriers to sustainable water-quality management. J Environ Manage 61:1-23.

[2] Bhagat, V.S. Use of remote sensing techniques for robust digital change detection of land: A review. Recent Pat. Space Technol. 2012, 2, 123-144.

[3] Mustafa, A. (2011) Land suitability analysis for different crops: a multi criteria decision making approach using remote sensing and GIS. Researcher, vol. 3, no. 12, pp. 61-84.

[4] Malczewski, J. (2004) GIS-based land-use suitability analysis: a critical overview. Prog. in Plan. 62, 3-65.

[5] Tomlin, C. (1990) Geographic Information Systems and Cartographic Modeling. Prentice Hall, New Jersey.

[6] FAO, (1993) Guidelines for land use planning. Development Series 1. Food and Agriculture Organization of the United Nations, Rome.

[7] Klosterman, R.K. (2001) Planning support systems: a new perspective on computer-aided planning, in Brail, R.K and Klosterman, R.E. (eds.). Planning Support Systems, ESRI Press, Redlands, CA, pp. 1-35.

[8] Saaty, T. (1980) The Analytic Hierarchy Process, New York: McGraw Hill.

[9] FAO, (1980) Land evaluation for development. Natural resources management and environment department, food and Agriculture organization of the United Nations, Rome.

[10] FAO, (1985) Guidelines: land evaluation for irrigated agriculture. Soils Bulletin 55, Food and Agriculture Organization of the United Nations, Rome.

[11] Saaty, T. L. (1977) A scaling method for priorities in hierarchical structures. Journal of mathematical psychology, 15(3), 234-281.

[12] Puntsag, G. (2014) Land suitability analysis for urban and agricultural land using GIS: Case study in Hvita to Hvita, Iceland. United Nations University Land Restoration Training Programme http://www.unulrt.is/static/fellows/document/Puntsag2014.pdf

[13] Hofstee, P. and M. Ir. Brussel, (1995) Analysis of suitability for urban expansion. http://www.itc.nl/ ilwis/applications/application21.asp Last accessed date: 17 th Nov. 2006.

[14] Engdawork, A. (2015) Characterization and classification of the major agricultural soils in cascape intervention woredas in the centeral highlands of Oromia region, Ethiopia. 